\title{
中性子スピンエコー法の多成分系への応用
}

遠藤 仁

(日本原子力研究開発機構 量子ビーム応用研究部門 分子生命科学研究ユニット 生体物質ダイナミクス研究グループ)

\section{Neutron Spin Echo Applied on Multi-component Systems}

Hitoshi Endo

Neutron Biophysics Group, Molecular Biology Research Division, Quantum Beam Science Directorate, Japan Atomic Energy Agency

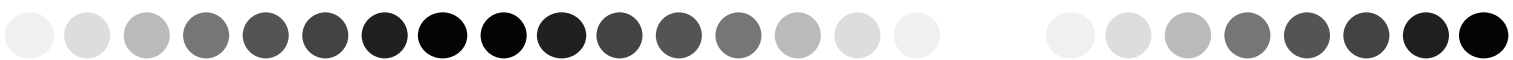

\begin{abstract}
The application of neutron spin echo technique on multi-component systems is introduced. As an example, dynamics of polyrotaxane studied by neutron spin echo with contrast variation method is reviewed. In addition, the current status of iNSE is briefly described.

Keywords: neutron spin echo, contrast variation, multi-component, supramolecule, polyrotaxane
\end{abstract}

1.はじめに

今回で 6 回目となる入門講座「中性子スピンエ コー」であるが，これまでの内容を簡単に振り返 りつつ，本稿の「多成分系への応用」へと文章を 進めて行く．従って，これ迄の入門講座「中性子 スピンエコー」の原稿を傍らに本稿を読み進めて 頂きたいと思う。

中性子スピンエコー法とは，非弾性散乱過程に おける散乱前後の中性子の速さの変化（＝エネ ルギーの変化）を，磁場中で歳差運動する偏極中 性子の回転数の違い（＝偏極度の差）として評 価する手法である。詳しい原理に関しては入門講 座第 1 回を参照して頂きたいが, 中性子スピンエ コー法の特に優れた特徵として,

- 観測值が動的相関関数 $\mathrm{G}(\mathrm{r}, \mathrm{t})$ ( $\mathrm{r}$ : 距離, $\mathrm{t}$ : 時間）の $\mathrm{r}$ 成分のみを散乱ベクトル $\mathrm{Q}$ でフー リエ変換した值, すなわち中間相関関数 $S(Q$, t)として直ちに評価される.

・ 波長分解能とエネルギー分解能が原理的には 完全に分離されており，入射中性子の単色化 を必要としない為, エネルギー分解能を上げ ても中性子強度が落ちない。

・ 中性子非弾性散乱測定法としてはナノ $\mathrm{eV}$ に 及ぶ最高のエネルギー分解能を誇る。

といった点が挙げられる。ソレノイドコイルで発 生する磁場を利用して偏極中性子の歳差運動を行 う Mezei 型スピンエコー分光器では, 歳差運動を
行う偏極中性子の量子化軸と中性子の進行方向が 一致するため, 中性子束の発散による磁場不均一 の補正を行う事が比較的容易である ${ }^{1}$. その為, 現 在稼働中の Mezei 型分光器の最大フーリエ時間は, ILL・IN15 の 1 マイクロ秒を筆頭に，標準的な性 能を有する東大物性研の iNSE 分光器でも定常的 に 50 ナノ秒での測定が可能である。一方, 共鳴型 スピンフリッパーを用いる共鳴スピンエコー法に おいては，歳差運動の量子化軸と中性子の進行方 向が直行するため, Mezei 型の様に効果的に中性 子束の発散を補正する方法が無く, 高分解能化は 一般には非常に困難である。しかしながら，装置 自体が非常にコンパクトであることから，偏極中 性子を用いる分光器にオプション的に導入するこ とが可能であり, Keimer らは偏極中性子三軸分光 器に共鳴型スピンフリッパーを用いたスピンエコ ーモードを導入し, 超伝導体のスローダイナミク スの研究を精力的におこなっている[1]. 共鳴スピ ンエコー法については，今後の日野らによる「入 門講座・中性子スピンエコー」で詳しく解説され る予定なので，そちらを参照してほしい。

\footnotetext{
入門講座「中性子スピンエコー」第 1 回 4 章参照. ${ }^{2}$ IN15の 1 マイクロ秒でエコーシグナルが観測された 結果は, 波長 $30 \AA$ 以上の中性子ダイレクトビームを用 いての測定であり，B. Farago らが最近磁場補正用に開 発したピタゴラスコイルのデモンストレーション的な 要素が大きく, 実際の試料を用いての実験はビーム強 度が弱い為に非常に困難である。それでも新規な磁場 補正素子を開発し，その性能の実証試験に成功した意 義は大きい.
} 
2. フーリエ時間とエネルギー分解能 ${ }^{3}$

モノクロメーターを用いた非弾性散乱法で観 測されるデータが $\mathrm{S}(\mathrm{Q}, \omega)$ （Q：散乱べクトル， $\hbar \omega$ : エネルギー遷移) であるのに対し, NSE で得 られるデータは $\mathrm{S}(\mathrm{Q}, \mathrm{t}) \quad(\mathrm{t}$ : フーリエ時間）であ ることは上述した通りである. $\mathrm{S}(\mathrm{Q}, \mathrm{t})$ は $\mathrm{S}(\mathrm{Q}, \omega)$ を 逆フーリエ変換して得られるので,

$$
S(Q, t) \propto \int_{-\infty}^{\infty} S(Q, \omega) \exp (-i \omega t) d \omega
$$

ここで励起の場合を考え，ボーズ因子を無視して $\mathrm{S}(\mathrm{Q}, \omega) \propto \delta\left(\omega+\omega_{0}\right)+\delta\left(\omega-\omega_{0}\right)$ として $(1)$ 式を解くと,

$$
S(Q, t) \propto \cos \left(\omega_{0} t\right)
$$

が導かれる. $\omega_{0}$ を間相関関数から決定する為に は最低 1 周期の測定が必要とすると, $\omega_{0} \mathrm{t}=2 \pi$ とい う関係式が得られる。 $\omega_{0}$ とエネルギー $\mathrm{E}_{0}$ はプラン ク定数 $\mathrm{h}$ を用いて $\mathrm{E}_{0}=\mathrm{h} \omega_{0} /(2 \pi)$ という関係式で結 ばれるので,

$$
E_{0}=h / t
$$

が得られる. (3)式は散乱ベクトル Q の定義式と結 晶面間隔 $\mathrm{d}$ に対寸るブラッグの法則を組み合わせ て得られる関係式 $\mathrm{Q}=2 \pi / \mathrm{d}$ と同じ程度の関係式で あり，フーリエ時間とエネルギーの関係を粗く見 積もる事が出来る。(3)式を用いると, フーリエ時 間 1 ナノ秒は約 4 マイクロ $\mathrm{eV}$ に, 1 マイクロ秒は 約 4 ナノ $\mathrm{eV}$ に相当する.

\section{3. 測定におけるバックグラウンド補正 ${ }^{4}$}

第 1 回入門講座第 5 章にまとめられている通り, NSE で得られるエコーシグナルは,

$$
\begin{aligned}
J & \propto I(Q, 0)+I(Q, t) \cdot \exp \left\{-\frac{\sigma^{2}(\delta \cdot \Delta B)^{2}}{2}\right\} \\
& \times \cos (\lambda \delta \cdot \Delta B)
\end{aligned}
$$

と記述される．ここで， $\sigma$ : 波長がガウス分布し ていると過程した場合の分散, $\Delta \mathrm{B}$ : 第一歳差磁場 之第二歳差磁場の磁場積分の差, $\lambda$ : 中性子の波 長である. $\delta$ は定数であり，

$$
\delta=\gamma_{L} m_{n} / h
$$

$\left(\gamma_{\mathrm{L}}\right.$ : 磁気角運動比, $\mathrm{m}_{\mathrm{n}}$ : 中性子質量, $\mathrm{h}$ : プラ ンク定数）で与えられる。エコーシグナルから $\mathrm{I}(\mathrm{Q}, \mathrm{t})$ と $\mathrm{I}(\mathrm{Q}, 0)$ が決定され，規格化された中間相関

\footnotetext{
3 入門講座「中性子スピンエコー」第 1 回 3 章参照.

4 入門講座「中性子スピンエコー」第 1 回 5 章参照.
}

関数 $\mathrm{I}(\mathrm{Q}, \mathrm{t}) / \mathrm{I}(\mathrm{Q}, 0)$ が評価される。 $\mathrm{I}(\mathrm{Q}, 0)$ は，2つの $\pi / 2$ フリッパーを off にし， $\pi$ フリッパーの on と off の強度（それぞれ $\mathrm{I}_{\mathrm{off}}, \mathrm{I}_{\mathrm{on}}$ と寸る）から精度良 く決めてやる事が出来る. 寸なわち,

$$
I(Q, 0)=\frac{I_{o f f}+I_{o n}}{2}
$$

である、また，スピンフリッパーの動作効率によ り中性子の偏極率は低下寸る。この効果も上述し た $\pi$ フッパーの on と off の強度から,

$$
\text { Polarization }=\frac{I_{o f f}-I_{o n}}{I_{o f f}+I_{o n}}
$$

を用いて評価する事ができる，従って，試料の規 格化された中間相関関数は,

$$
\begin{aligned}
{\left[\frac{I(Q, t)}{I(Q, 0)}\right]_{S m p} } & =\left\{\frac{2 I_{S m p}(Q, t)}{I_{o f f}^{S m p}+I_{o n}^{S m p}}\right\}\left\{\left(\frac{I_{o f f}^{S m p}-I_{o n}^{S m p}}{I_{o f f}^{S m p}+I_{o n}^{S m p}}\right)\right. \\
& =\frac{2 I_{S m p}(Q, t)}{I_{o f f}^{S m p}-I_{o n}^{S m p}}
\end{aligned}
$$

と表される。(4)式において，理想的には $\mathrm{I}(\mathrm{Q}, \mathrm{t})$, $\mathrm{I}(\mathrm{Q}, 0)$ 以外は測定に依らずに一定值を取るのだが, 実際には中性子の光路差及び歳差磁場の不均一性 により歳差磁場強度を変えた場合の位相差は一定 とならない。この補正は, 弾性散乱が強い物質を 標準試料として用いることで行う。すなわち, 標 準試料を用いて同じ環境で測定を行った規格化中 間相関関数を用いて補正を行う。

$$
\left[\frac{I(Q, t)}{I(Q, 0)}\right]_{S m p}^{A b s}=\left\{\frac{2 I_{S m p}(Q, t)}{I_{o f f}^{S m p}-I_{o n}^{S m p}}\right\}\left\{\frac{2 I_{S t d}(Q, t)}{I_{o f f}^{S t d}-I_{o n}^{S t d}}\right\}
$$

ここで, $2 \mathrm{I}_{\mathrm{Std}}(\mathrm{Q}, \mathrm{t}) /\left(\mathrm{I}^{\mathrm{Std}}{ }_{\text {off }}-\mathrm{I}^{\mathrm{Std}}{ }_{\text {on }}\right)$ が NSE 法の分解能関 数である.

小角散乱と同様, NSE のシグナルも溶媒等のバ ックグラウンド散乱の影響を受ける.この補正は, (8)式を

$$
\left[\frac{I(Q, t)}{I(Q, 0)}\right]_{S m p}=\frac{2\left\{I_{S m p}(Q, t)-T r \cdot I_{B g r}(Q, t)\right\}}{I_{o f f}^{S n p}-I_{o n}^{S m p}-T r \cdot \phi\left(I_{o f f}^{B g r}-I_{o n}^{B g r}\right)}
$$

と置き換える事で行う。ここで, $\mathrm{Tr}$ : バックグラ ウンドに対する試料の透過率， $\phi$ : バックグラウ ンドの体積分率である. $\mathrm{I}_{\mathrm{Bgr}}(\mathrm{Q}, \mathrm{t})$ : バックグラウン ドのエコーシグナルの振幅, $\mathrm{I}^{\mathrm{Bgr}}{ }_{\mathrm{off}}-\mathrm{I}^{\mathrm{Bgr}}{ }_{\mathrm{on}}$ : バック 
グラウンドの偏極率測定からの值であり，実際に バックグラウンド測定を行う事で決定する.

$\mathrm{I}_{\mathrm{Bgr}}(\mathrm{Q}, \mathrm{t})$ は, バックグラウンドのダイナミクスの影 響を除く為の項であるが，溶媒の動きが溶質のも のより十分速い場合は殆ど影響無い. 分母の $\mathrm{I}^{\mathrm{Bgr}}$ off - $\mathrm{I}^{\mathrm{Bgr}}{ }_{\mathrm{on}}$ の項は, 溶質の散乱強度とバックグラウン ドの散乱強度が拮抗する場合には中間相関関数の 規格化に非常に効いてくる. バックグラウンドの 影響は中性子小角散乱（SANS）のデータからも ある程度見積もる事が出来るので, NSE 測定にお いてはその測定值の妥当性を議論する為にも SANS 測定が必須である。

また, 2 次元検出器上で広い範囲から強度を積 算しようとすると，位相差のずれが大きくなり， 観測されるエコーシグナルは不明膫となる。この 際, 位相差を磁場積分に依存寸るものと検出器位 置に依存するものとに分離してより多くの 2 次元 検出器の範囲から強度積算を可能に寸る方法が山 田らによって開発され, iNSEではその方法を採用 し測定効率を上げる事に成功している. 詳細は文 献[2]を参照されたい.

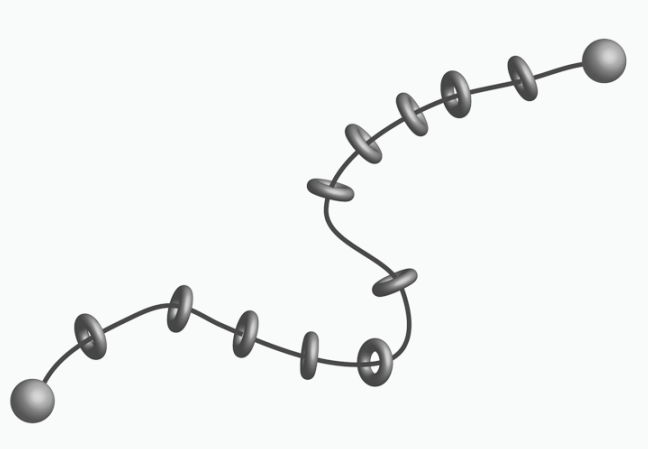

Fig.1 Schematic illustration of polyrotaxane.

\section{4. 多成分系ソフトマターへの応用}

Mezei 型の高分解能スピンエコー分光装置が強 みを発揮する対象は, ソフトマターの緩和現象を 中心とするスローダイナミクスに関する研究であ る. その中でも, 高分子ダイナミクスの研究にお いて NSE の果たした貢献は特に大きいものであ った ${ }^{5}$. 最近, 筆者らはトポロジカルに結合した「超 分子構造」を持つ高分子であるポリロタキサンの 静的動的構造を, コントラスト変調中性子散乱法 を駆使して研究している. その研究はまだ途上に あるのだが，この章でその一部を紹介したいと思 う。

ポリロタキサンとは, 線状高分子を軸として多 数の環状分子が連なった構造をしており（Fig. 1), 大阪大学の原田らが最初に合成に成功した[3]. 線 状高分子として代表的な水溶性高分子であるポリ エチレングリコールを, 環状分子としては 6 個の
グルコースが環状に結合した $\alpha$-シクロデキスト リンを用いた物が一般的であるが, その後, 各種 のポリロタキサンが合成されている[4]. 今世紀冒 頭に東京大学の奥村泰志 (現 -九州大学) - 伊藤耕 三らが「環動ゲル」と呼ばれる新奇な物質を開発 して以来, ポリロタキサンは応用面でも注目され る様になった[5].「環動ゲル」とは，ポリロタキ サンの環状分子の一部を「8 の字」状に架橋した ゲルで, 吸水性に優れるが力学的に脆いという従 来のゲルの常識に反し, 吸水性に優れるという特 性そのままに高弾性かつ耐摩耗性に優れる等, 力 学的強度にも非常に優れた物質である.これらの 特徵は, 架橋点が可動であることから生じると予 測されているが，ポリロタキサン及び環動ゲルの 物性に関する分子論的研究は未だ開始されたばか りというのが現時点の状況である.

ポリロタキサンは高分子の一種と言えるが, 環 状分子のスライドと回転という内部自由度を有す る等, 従来の高分子とは異なった観点からその物 性を評価する必要がある。実際，ポリロタキサン の動的性質を動的光散乱で評価した研究例があり, 得られた動的構造因子をCONTIN 法というラプ ラス変換の一種を用いて各運動モードを評価した 結果, 環状分子のスライド運動が軸高分子のセグ メント運動よりも速いという事が示唆されたが, 分子論に基づく定量的な解析を行う様な定量的な データは得られなかった[6]. 我々は, ポリロタキ サンを「軸となる線状高分子」と「軸に連なる環 状分子」から成る複合系と見なし, 部分重水素化 した試料を合成して中性子散乱測定を行い，この 二つの成分の散乱シグナルを分離して環状分子の 静的動的性質を分子論的に議論する事を試みた.

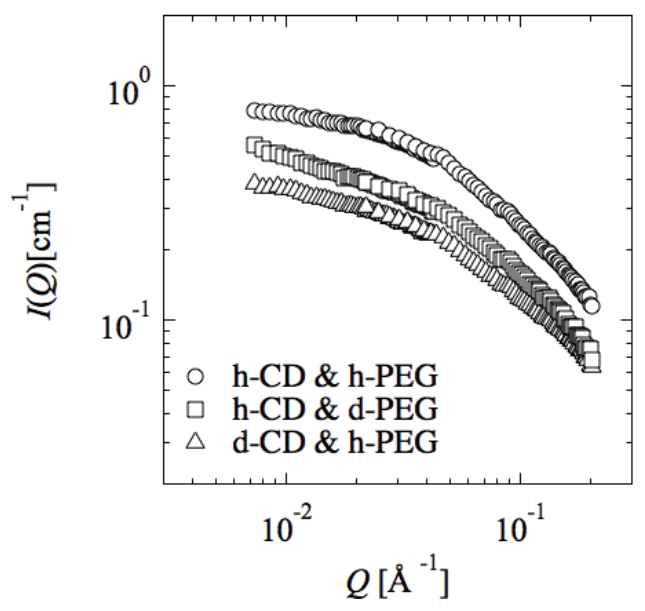

Fig.2 Contrast variation small-angle neutron scattering results for polyrotaxane (PR) with different deuteration: (O) PR with both protonated axial polymer and cyclic molecules, ( $\square$ ) PR with partially deuterated axial polymer and protonated cyclic molecules, and $(\triangle) P R$ with protonated axial polymer and partially deuterated cyclic molecules.

${ }^{5}$ 入門講座「中性子スピンエコー」第 3 回参照. 
ポリロタキサンの静的構造因子は, 以下の式で 与えられる。

$$
\begin{aligned}
I(Q) & =\Delta \rho_{C} S_{C C}(Q)+2 \Delta \rho_{C} \Delta \rho_{P} S_{C P}(Q) \\
& +\Delta \rho_{P} S_{P P}(Q)
\end{aligned}
$$

ここで， $\Delta \rho_{\mathrm{l}}$ は成分 $\mathrm{i}(\mathrm{i}=\mathrm{C}, \mathrm{P} ; \mathrm{C}$ : 環状分子, $\mathrm{P}$ : 軸高分子) と溶媒との散乱長密度の差, $\mathrm{S}_{\mathrm{ij}}(\mathrm{Q})$ は部 分散乱関数で, $\mathrm{S}_{\mathrm{CC}}(\mathrm{Q})$ は環状分子からの, $\mathrm{S}_{\mathrm{PP}}(\mathrm{Q})$ は軸高分子からの散乱寄与である。 $\mathrm{S}_{\mathrm{CP}}(\mathrm{Q})$ は環状 分子と軸高分子との対相関を反映した散乱寄与で あり, $\mathrm{S}_{\mathrm{CP}}(\mathrm{Q})$ を直接検証することで環状分子と軸 高分子との相互作用を決定する事が出来る. 式を中間相関関数に拡張すると,

$$
\begin{aligned}
\frac{I(Q, t)}{I(Q, 0)}= & \frac{\Delta \rho_{C} S_{C C}(Q, t)+2 \Delta \rho_{C} \Delta \rho_{P} S_{C P}(Q, t)}{\Delta \rho_{C} S_{C C}(Q, 0)+2 \Delta \rho_{C} \Delta \rho_{P} S_{C P}(Q, 0)} \\
& +\Delta \rho_{P} S_{P P}(Q, 0)
\end{aligned}
$$

が得られる。すなわち, ポリロタキサン中の環状 分子のダイナミクスを評価する為には，(12)式中 の $\mathrm{S}_{\mathrm{CC}}(\mathrm{Q}, \mathrm{t})$ と $\mathrm{S}_{\mathrm{CP}}(\mathrm{Q}, \mathrm{t})$ とを何らかの方法で分離して 個別に評価する必要がある。中性子を散乱のプロ 一ブとした場合, 軽水素と重水素の散乱長密度が 大きく異なる事を利用したコントラスト変調法が 可能となる．我々は，軸高分子並びに環状分子を 選択的に部分重水素化することでコントラスト変 調中性子小角散乱並びにコントラスト変調中性子 スピンエコー実験を行った。 具体的には，(i)環状 分子と軸高分子共に軽水素から成るポリロタキサ ン, (ii)環状分子のみ部分重水素化したポリロタキ サン, (iii)軸高分子の夕部分重水素化したポリロタ キサン，の 3 種のポリロタキサンを合成すること でコントラスト変調中性子散乱実験を行った。試 料は, 軽水素換算で分子量 2 万 $\mathrm{g} / \mathrm{mol}$ のポリエチ



Fig.3 Intermediate scattering functions for polyrotaxane in dimethyl sulfoxide with different deuteration (see the caption in Fig.2).
レングリコールを用いて合成したポリロタキサン を良溶媒である重水素化ジメチルスルホキシド

(DMSO) 中にそれぞれ体積分率 $8 \%$ で溶解させた ものを用いた. Fig.2 に部分重水素化した成分の異 なるポリロタキサンの中性子小角散乱プロファイ ルを示す。散乱強度は大きい順から軽水素から成 るポリロタキサン，軸高分子を部分重水素化した ポリロタキサン，環状分子を部分重水素化したポ リロタキサンとなる。強度の差と $\mathrm{Q}>0.1 \AA^{-1}$ の領 域における各散乱強度のスロープの違いから, 各 コントラストでの部分散乱関数の寄与が大きく異 なっている事が分かる。これらの試料を用いて中 性子スピンエコー測定を行った結果を Fig.3 に示 す. 中性子スピンエコー測定はドイツ FRM-II 研 究原子炉に設置されている J-NSE 分光器を用い, $\mathrm{Q}$ 領域を $0.05 \leq \mathrm{Q}\left[\AA^{-1}\right] \leq 0.15$ の範囲で，最大フー リエ時間を 30 ナノ秒に設定した。 Fig.3 の通り, 各コントラストでの中間相関関数に明瞭な差は見 られなかった.この結果から, 動的光散乱の結果 に基づく環状分子のスライド運動が軸高分子のセ グメント運動より速いという予測は，完全に否定 された，残る可能性は，環状分子と軸高分子の運 動速度が全く同じ場合と，環状分子のスライド運 動が軸高分子のセグメント運動より遅い場合であ り，現在，この $2 つ の$ 可能性に関して理論及び実 験両面から検証を行っている.

以上の通り，中性子スピンエコーにコントラス 卜変調法を組み合わせる事によって，多成分系の ダイナミクスの詳細をナノメートル・ナノ秒の時 空間スケールで定量的に検証する事が初めて可能 になる。この様に，多成分系の研究において，コ

(a)

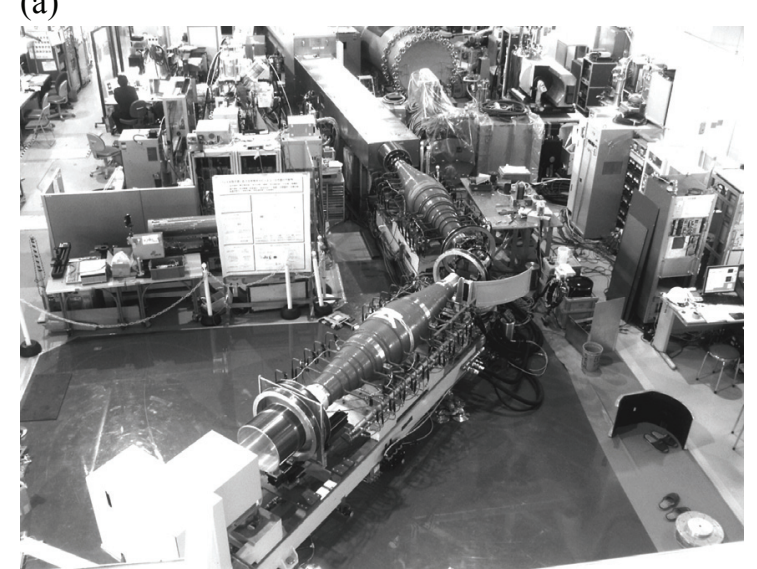

(b)



Fig.4 (a) Picture of iNSE at C-2-3-1 beam port in the experimental hall of JRR-3. (b) Overview of iNSE. 
ントラスト変調法を活用した中性子散乱は現時点 で最良の実験手法であり，日本・米国・欧州の 3 極で第二世代スパレーション中性子源の開発が進 む 21 世紀前半においてその優位性はしばらく摇 るが無いであるう。

\section{5. iNSE の現状}

iNSE 分光器は, 1990 年代に広島大学の好村滋 洋・武田隆義・瀬戸秀紀（現・KEK）らの尽力で JRR-3 の実験ガイドホールで建設が進められた[7]. 建造当初は，ISSP-NSE という名称で C2-2 ビーム ポートに設置されていたが, 2003 年に東京大学の 長尾道弘（現・NIST）らによって C2-3-1 ビーム ポートへ移設され，iNSE と改称された[8]. 移設 と同時に大幅な改良が為され，ビームの単色化， 偏極化, 偏極アナライザ, 検出器, 2nd $\pi / 2$ フリッ パーの大型化，補正コイルの大型化が成された。

Fig.4に現在の iNSE の写真及び概略図を示す.

更に, 平成 20 年度より文科省「原子力基礎基 盤戦略研究イニシアティブ」に「原子炉型中性子 小角散乱分光器群の先鋭的高度化に関する研究

(代表 : 柴山充弘東京大学教授)」が採用され，そ

(a)

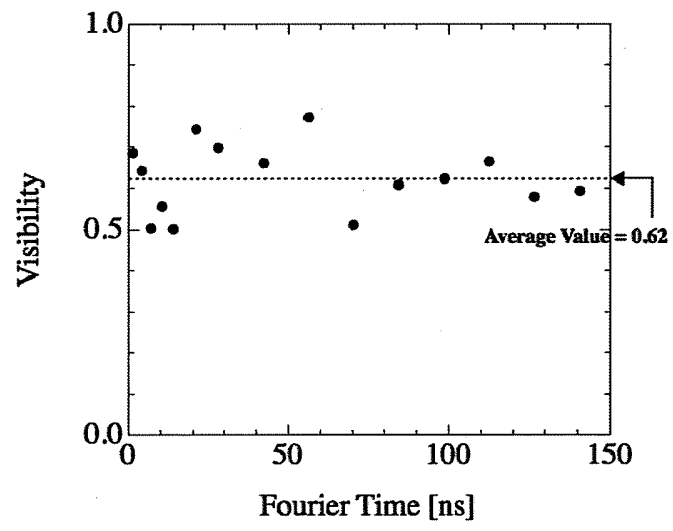

(b)

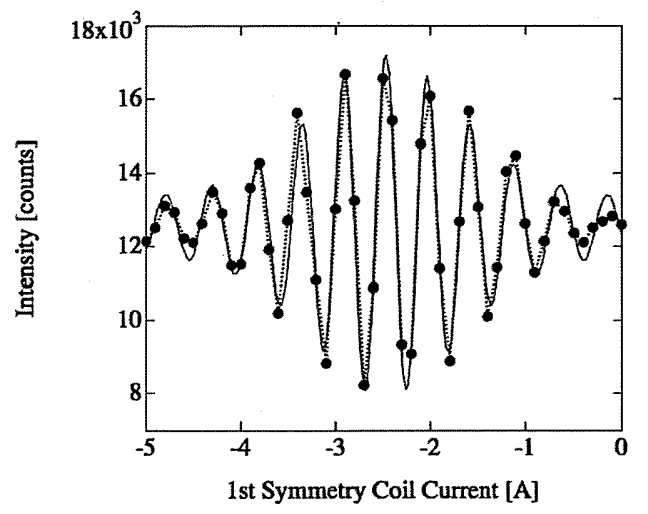

Fig.5 (a) Visibility of echo signals with direct beam of $15.8 \AA$ wavelength neutrons as a function of Fourier time. (b) Echo signal with direct beam of $15.8 \AA$ wavelength neutrons at $0.22 \mathrm{Tm}$ magnetic field, in which the corresponding Fourier time is $141 \mathrm{~ns}$.
の一環としてiNSEの一層の高度化が進められた。 その結果，現在，Fig.5 に示守通り，中性子波長 $15.8 \AA$ を用いて明瞭なエコーシグナルの観測に成 功し, 最大フーリ工時閒は 140 ナノ秒にまで到達 している.

6.まとめ

以上で入門講座「中性子スピンエコー」第 6 回 を終えるが，元々は「多成分系への応用」という 主題で書く予定であったものが，「これ迄の小まと め及び補足」の部分と「iNSEの現状」を加え，広 範な内容になってしまった。これ迄の入門講座の 記述に頼っていて理解し難い部分もあるかとは思 うが，以前と重複している箘所は重要な部分と思 って頂いて，第 1 回〜第 5 回までの原稿を読み返 す契機になれば幸いである。しかしながら，より 良い理解には中性子スピンエコー测定を一度行っ てみるに越した事は無いので，入門講座「中性子 スピンエコー」を読んで興味を持たれた方は，是 非 NSE 測定に挑戦して頂きたい。最後に，原稿の 締め切りを度々破り多大なご迷惑をお懸けした首 都大学東京・川端庸平氏をはじめ波紋編集委員の 方々にお詫び申し上げて，筆を擱く。

謝辞

今回の記事の研究成果の一部は, 文部科学省「原 子力基礎基盤戦略研究イニシアティブ」から予算 支援を受けて行ったものです. iNSE 分光器の Upgrade に関しては, KEK・山田悟史博士に多く の協力と助言を頂きました。また，ポリロタキサ ンの研究においては，東大・廝弓皓一氏，NIST ・ 長尾道弘博士らと研究を進めてきました。この場 を借りて感謝致します。

参考文献

[1] P. Aynajian et al., Science 319, 1509-1512 (2008).

[2] 山田悟史ら，波紋 17, 132-135 (2007).

[3] A. Harada et al., Nature 356, 325-327 (1992).

[4] A. Harada et al., Chem. Rev. 109, 5974-6023 (2009).

[5] Y.Okumura and K. Ito, Adv. Mater. 13, 485-487 (2001).

[6] C. Zhao et al., J. Phys. Condens. Matter 17. S2841-S2846 (2005).

[7] T. Takeda et al., Nucl. Instr. and Meth. in Phys. Res. A 364, 186-192 (1995).

[8] M. Nagao etal., Physica B 385-386, 1118-1121 (2006). 